\title{
Enhanced Cooperation in the EU: Its Evolution and Position of the Czech Republic ${ }^{1}$
}

\begin{abstract}
Enhanced cooperation (originally closer cooperation) was inserted into the EU institutional and legal system by the Amsterdam Treaty in a response to political calls for establishment of a mechanism that would allow for deeper integration of only some Member States ("coalitions of the willing") in the ever-enlarging EU. As such, this step meant a break with the unity dogma the European integration had been traditionally built upon and provided for institutionalised differentiation in the EU. Redesigned by both the Treaty of Nice and the Treaty of Lisbon, enhanced cooperation has materialized in 5 cases since 2010. Apart from that, possibility of a recourse to enhanced cooperation has played a role in negotiation strategies within the EU decision-making process and in reflections on the future of the EU. While enhanced cooperation is not a magic panacea to divergences of opinions on the European integration between individual Member States, in particular, middle-sized and small Member States including the Czech Republic shall not underestimate the potential this mechanism might have.
\end{abstract}

Key words: European Union, Closer Cooperation, Enhanced Cooperation, Flexibility, Czech Republic

\section{Introduction}

Although the official motto of the European Union (EU) adopted in 2000 describes the EU as the union of States "united in diversity"

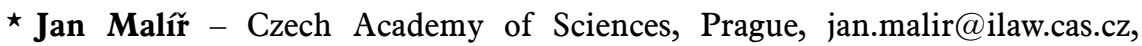
ORCID: 0000-0001-9861-4876.

1 This text was made possible thanks to support from the Ministry of Foreign Affairs of Republic of Poland (Polish-Czech Forum for the rapprochement of societies, deeper cooperation and good neighbourhood 2018) and from the Czech Academy of Sciences (RVO: 68378122).
} 
(in varietate concordia), the institutional and legal system of the $\mathrm{EU}$ has been traditionally built on what has come to be designated as the unity dogma in the recent years. In view of the circumstances in which the process of the supranational European integration was launched in the 1950s and, in particular, the specific political goals which this process has pursued ever since, there is no wonder why such a stress has been put on unity and synchronicity, whether in elaboration of the EU policies, EU decisionmaking or application of the common rules. In a way, over the decades, the unity has been transformed into a kind of the principal constitutive myths that the European integration is based on. Correspondingly, the unity dogma has turned into the key point any debate on the EU must depart from.

However, as a result of developments such as deepening of the European integration, its expansion into new areas or the ongoing enlargement of the EU (leading to the substantial rise of the number of Member States), the environment in which the European integration takes place has markedly changed. Correspondingly, it has become increasingly difficult to assert the unity not only with respect to the overall goals of the integration process but the pace and degree of integration in individual areas as well.

This state of affairs is not surprising. Albeit a keen supporter of the European unity, Bronislaw Geremek, great Polish historian, once aptly observed there had always been manifold differences between European States. As he pointed out, these differences sometimes dated very far to history and frequently related to a wide array of factors that range from geography to varying cultural patterns. ${ }^{2}$ Although the European in tegration itself, the rise of consumer society or globalisation have contributed to substantially narrowing many of the differences which once existed between the European States, interests and policy choices of $28 \mathrm{Member}$ States of the EU have not become completely identical and, actually, cannot be, at least for the time being, systematically identical. These differences in interests and policy choices are not definitely limited to the "old" and "new" Member States divide as many journalists let pretend these days Frequently, they continue to reflect geographic, economic or cultural diversity of the EU. Member States. In this respect, one may point to differences between the Member States with the status of (at least) regional powers and the other Member States or between Northern and Southern Member States. There are also differences between Member

2 B. Geremek, L'élargisement et l'unité de l'Europe. Speech pronounced at the annual conference of doctoral studies at Sciences Politiques in Paris, 27 January 2004, https://www.robert-schuman.eu/fr/doc/actualites/elargissement-geremek.pdf (10.11.2018). 
States, which possess territorial sea, and those, which are landlocked. In addition, there are Member States whose economic system focuses on providing financial services and those whose economy builds on robust industrial production. Similarly, there are Member States with the strong Catholic legacy as there are Member States with the strong Protestant legacy. Last but not least, there are Member States with and without the colonial past.

In fact, differences in terms of interests and policy choices do exist even between the Member States which are normally thought to be close to each other. By way of example, Poland and the Czech Republic are considered to be related through their neighbourhood, the Visegrad cooperation, shared modern history or the common Slavic origins. However, even if the stark difference in size between the two countries is left aside, while Poland has a natural and vital interest in navigation and fishery in the Baltic sea region, from the Czech point of view, these are not the primary issues. Comparably, whereas Polish robust agriculture production accounts for some $12,6 \%$ of employments, in the Czech Republic, the figure is only $1,9 \%$ which means sensitivity to issues linked to agricultural policy may differ between these two Member States.

Due to these differences, Member States may legitimately have and indeed have - different opinions on what the goals of European integration shall be, whether in specific areas or when it comes to the integration process as a whole. These differences of opinions, in turn, result in adoption of different - or even conflicting - positions within the EU decision-making process and in a split of the Member States into groups that want to further pursue European integration in some form and those which prefer to remain upon the existing level of integration. Such situations pose an existential dilemma whether to insist on unity or to permit a differentiation ${ }^{3}$ (in French, différenciation) between Member States in the EU.

On practical political and legal level, by now, this dilemma has been to certain extent resolved. The unity dogma has been gradually relaxed and certain extent of differentiation between the Member States has been admitted. While some elements of differentiation can be actually traced back to the very beginning of the European Communities in the $1950 \mathrm{~s},{ }^{4}$ since the elaboration of the Single European Act in the 1980s,

3 "Flexibility" is frequently used as a synonym; however, as the term of flexibility is also employed with respect to provisions which allow for the extension of the EU powers, in particular, Article 352 TFEU, in the sake of clarity, it is preferred to use "differentiation" in this text.

4 Such as the existence of the Benelux. 
differentiation has become a real issue on the EU political and legal agenda. At first, the political will to admit certain differentiation in the framework of European integration manifested itself in the rise of opt-outs granted on ad hoc basis to individual Member States that were not willing to accept the expansion of European integration. The same was true of the novel instruments based on international law and negotiated outside the scope of EC law that permitted the groups of the willing Member States to proceed with cooperation and integration further. The next step came, however, with insertion of the specific mechanisms into the Founding Treaties that allow for what might be called institutionalized differentiation. Although the recourse to these mechanisms has not been massive in everyday practice, their very existence is a clear proof that differentiation is not incompatible with the idea of the European integration any more.

This is not to say that the departure from the unity dogma and admission of differentiation in the EU has come unnoticed or that it has been universally accepted. In fact, the issue of differentiation in the EU and its permissible extent has triggered important and rather emotional debate which lasts up to date and which is of profound importance for the future of the whole process of European integration. Several theoric models have been elaborated by political scientists and European integration theorists to describe the possible patterns of differentiation and their political, and economic impacts on the relationships inside the EU. These models, as it is well known, range from multispeed Europe to two-speed Europe (also known as noyau dur/ core Europe) via Europe à la carte..$^{5}$ Although merely theoric, these models continue to serve as point of reference in the debate that goes on.

Just a few years ago, the opinion prevailed that the issue of differentiation must be open only with a great care. It was not unusual to hear that the risks resulting from differentiation exceed the benefits it can have in a long term. Since then, experience gained from such developments such as ratification of the Treaty establishing a Constitution for Europe or search for the strategy in the sovereign debt crisis has contributed to a change in approach. By now, differentiation has not been a marginal or unwanted topic any more.

A clear sign of this trend, when the European Commission published its "White paper on the future of Europe" at the occasion of $70^{\text {th }}$

5 For an overview of these models, see e.g.: D. Thym, Competing Models for understanding differentiated integration, in: Between Flexibility and Disintegration. The Trajectory of Differentiation in EU Law, eds. B. de Witte, A. Ott, E. Vos, Elgar, CheltenhamNorthampton 2017, pp. 32-36; for detailed treatment see e.g.: A. Stubb, Negotiating Flexibility in the European Union, Palgrave, Houndmills 2002, pp. 30-57. 
anniversary of the Treaties of Rome, it identified differentiation as one of the principal directions in which the EU institutional and legal system might evolve in future. ${ }^{6}$ It is, in particular, under Scenario 3 as described in the White paper that the Member States wishing to achieve more integration shall be principally allowed to do so. More precisely, coalitions of the willing Member States might be permitted "to deepen their cooperation in chosen domains" while "[t]he status of other Member States is preserved, and they retain the possibility to join those doing more over time" under this Scenario. ${ }^{7}$

It is especially the mechanism called enhanced cooperation that might be employed as the privileged instrument were the Scenario 3 to receive political support in future. But even if Scenario 3 were not the one the EU will choose, this mechanism has inherent potential to contribute to easing the tensions between the differing views on the goals of the European project and its finality.

\section{The Origins of the Enhanced Cooperation: Closer Cooperation under the Amsterdam Treaty}

The origins of the present enhanced cooperation can be traced back to the Amsterdam Treaty. At the beginning of the negotiations that led to its conclusion, in a joint letter to the Presidency of the European Council in December 1995, J. Chirac, the President of France, and H. Kohl, the Prime Minister of Germany, expressed their conviction that all the Member States should normally take part in the integration process on the same terms. In the same letter, however, they proposed that where one or more Member States were confronted with the temporary difficulties in keeping up with the pace of progress, the rest of the Member States should have a chance of pursuing the closer cooperation within the framework of the EU. ${ }^{8}$

Such proposal was not completely new. Not only the issues of differentiation and suitable models of differentiated integration were occasionally discussed in political and legal doctrine before but, during the successive amendments of the Treaties and the expansion of the

6 European Commission, "White paper on the future of Europe. Reflections and scenarios for the EU27 by 2025", COM(2017) 2025 final, 1 March 2017.

7 Ibidem, p. 11.

8 R. Böttner, The Development of Flexible Integration in EC/EU Practice, in: Flexibility in the EU and Beyond. How Much Differentiation Can European Integration Bear?, eds. T. Giegerich, D.C. Schmitt, S. Zeitzmann, Nomos - Hart Publishing, BadenBaden-Oxford 2017, p. 77. 
integration project to new areas, differentiation was an inevitable price paid for the possibility to go ahead. After the elaboration of the Single European Act, it became apparent that not all the Member States were systematically willing to accept the integration at the same speed and at the same extent which, simultaneously, posed a serious challenge to the "unity dogma". Although the Maastricht Treaty of 1992 put an express emphasize on the fact the principal goal of the newly established EU was to bring about "an ever closer union among the peoples of Europe" (now Article 1 TEU), by the time of the signature of this historical Treaty, differentiation actually started to demonstrate itself, albeit, at that time, on an ad hoc basis. ${ }^{9}$

As early as in this period, otherwise known for optimist and ambitiously pro-integration atmosphere, the Member States were, thus, obliged to abandon the unity dogma in order to gain support for the redesign of the EU institutional and legal system. To cite just the most notorious examples, the United Kingdom had to be granted opt-out from the Social Policy introduced by the Maastricht Treaty ${ }^{10}$ and Denmark and the United Kingdom had to be granted the permanent opt-out from the third stage of the EMU programmed by the same Treaty ${ }^{11}$. Similarly, when, a few years before the Maastricht Treaty, an idea appeared that controls of persons at the internal borders between the Member States should be abolished in extension to free movement of persons in the ECs, it did not receive the general support from all the Member States. Consequently, the abolition of controls at the internal borders had to be achieved by a group of the Member States outside the scope of EC law and that by means of agreements concluded under international public law known as the Schengen agreements. ${ }^{12}$

9 For more detailed treatment, see e.g.: ibidem, pp. 61-76.

10 Protocol on Social Policy, to which is annexed an agreement concluded between the Member States of the European Community with the exception of the United Kingdom of Great Britain and Northern Ireland, to which two declarations are attached, OJ C 191, 29 July1992, p. 95.

11 Protocol on certain provisions relating to Denmark and Protocol on certain provisions relating to the United Kingdom of Great Britain and Northern Ireland, OJ C 191, 29 July 1992, p. 95.

12 Agreement between the Governments of the States of the Benelux Economic Union, the Federal Republic of Germany and the French Republic on the gradual abolition of checks at their common borders, signed on 14 June 1985 and Convention implementing the Schengen Agreement of 14 June 1985 between the Governments of the States of the Benelux Economic Union, the Federal Republic of Germany and the French Republic on the gradual abolition of checks at their common borders, signed on 19 June 1990. 
With the Chirac-Kohl's letter of 1995, however, it was actually the first time that the issue of institutionalization of the differentiation in the ECs/ EU indeed appeared on the agenda of intergovernmental conference whose task was to negotiate amendments of the Treaties. The Franco-German backing in conjunction with the prospect of the further enlargements of the EU already at the horizon contributed to the fact that the proposal gained momentum and materialized in the Amsterdam Treaty provisions on what, at the time, came to be designated as closer cooperation.

By inserting a new title into the Treaty on European Union (Articles 40-45 TEU, ex Articles K.12-K.17 TEU), the Amsterdam Treaty provided for the possibility of setting up closer cooperation between the Member States which would either wish to deepen their cooperation in an area already covered by EC law, or extend their cooperation into a completely new area. In such an area, only the Member States participating in closer cooperation would adopt legal acts and only these participating Member States would be bound by these acts (K 43 (2) TEU). What was more, the possibility to launch closer cooperation was not limited to the European Communities or the $1^{\text {st }}$ Pillar of the EU but, albeit under special rules, the possibility of launching closer cooperation was expressly provided for also in the framework of Justice and Home Affairs or the $3^{\text {rd }}$ Pillar of the EU, i.e. area linked to the core of national sovereignty of Member States (Article 40 TEU).

In instituting closer cooperation, no doubt, the Amsterdam Treaty made an important shift in the EC/EU design. While, before its conclusion and entry into force, differentiation might have been merely established ad hoc and that either by means of the opt-outs from the scope of the Treaties or international agreements concluded outside EC law, the Amsterdam Treaty laid down foundations for institutionalisation of differentiation within EC/EU law.

On the other hand, the drafters of the Amsterdam Treaty felt it necessary to counterbalance potential threats that might have resulted from this break with the unity dogma. In order to avoid the risk that closer cooperation would produce the split of the EU into a web of alliances of the Member States that would finish by their competition setting up closer cooperation was made subject to strict conditions of both material and procedural character. As for material conditions, TEU as amended by the Amsterdam Treaty laid down 7 principal ones and 5 additional ones (Article 43 (1) TEU). Most notably, closer cooperation under the Amsterdam Treaty had to include at least the majority of the Member States, could only be used as a last resort where the goals aimed at could not be attained within the standard decision-making process, 
and had to be open to all Member States. As for procedural conditions, in the $1^{\text {st }}$ Pillar (Article 11 (2) EEC Treaty, ex Article 5a EEC Treaty), closer cooperation must have been authorised by the Council on a proposal from the Commission and after consulting the European Parliament. ${ }^{13}$ The Council was to vote by qualified majority, however, each Member State was guaranteed a right of veto as it was allowed to oppose authorisation by invoking "important and stated reasons of national policy". ${ }^{14}$ In such a case, the only way how to have closer cooperation authorised was to refer the issue to the Council meeting in the composition of the Heads of State or Government. Nevertheless, the Council meeting in such a top composition would decide by unanimity which would effectively conserve the right of veto for each Member States. In the $3^{\text {rd }}$ Pillar, procedural conditions differed in certain aspects (Article $40 \mathrm{TEU}$ ).

As a whole, both material and procedural conditions were assessed to be so demanding that doubts were widely expressed over the chance of setting up closer cooperation in practice. And, indeed, under the Amsterdam Treaty, no closer cooperation came into existence. Consequently, the shift from the unity dogma to institutionalised differentiation largely remained on paper. Yet, the existence of closer cooperation played some role. The prospect of closer cooperation was reported to have namely contributed to persuading Spain to withdraw its opposition to the proposal of the Societas Europea Statute. The idea that closer cooperation could be set up was repeatedly mentioned also in other contexts. ${ }^{15}$

These facts are of interest up to date as they demonstrate that, contrary to what is often alleged, enhanced cooperation, in practice, does not necessarily have to lead to differentiation between the Member States but, vice versa, it may serve as political stimulus which, ultimately, may bring about the increased unity between the Member States.

\section{From Closer Cooperation to Enhanced Cooperation: Treaty of Nice}

Soon, the mechanism of closer cooperation as established by the Amsterdam Treaty was transformed by the Treaty of Nice. That was

13 G. Isaac, M. Blanquet, Droit général de l'Union européenne, 10eédition, Sirey, Paris 2012, pp. 45-46.

14 Formulation strongly reminiscent of the wording of the Luxembourg compromise of 1966.

15 J. Shaw, Enhancing Cooperation after Nice, in: M. Andenas, J. Usher, The Treaty of Nice and Beyond: Enlargement and Constitutional Reform, Hart Publishing, Oxford 2003, p. 217. 
rather surprising as the issue of differentiation was not originally expected to be on the agenda of the 2000 intergovernmental conference whose primary goal was to adapt EC/EU institutional and legal system before the next waves of enlargements. It was especially the pressure from the Six Founding Member States that contributed to the fact closer cooperation became subject to negotiations and was linked to the enlargement agenda. As a result, the Treaty of Nice amended the corresponding provisions of the Treaties. The extent of the amendments was far from being cosmetic and the whole mechanism was actually redesigned. That was reflected also on a symbolic level as the mechanism was renamed from "closer cooperation" to "enhanced cooperation", a title, that the mechanism bears up to date. ${ }^{16}$

To mention just the most important transformations which resulted from the Treaty of Nice, firstly, the Treaty of Nice effectively suppressed the right of veto all the Member States originally enjoyed as mentioned supra. ${ }^{17}$ Under the Treaty of Nice, the decision authorising enhanced cooperation was to be taken by qualified majority in the Council. The truth is that if the opposing Member State requested, the matter of authorisation would be referred to the European Council. However, unlike under the Amsterdam Treaty, the European Council would not vote by unanimity but, henceforward, by a qualified majority (11 (2) EC Treaty).

Secondly, some of the material conditions for setting up enhanced cooperation were reformulated. The minimum number of the Member States necessary to participate in enhanced cooperation was reduced to 8 (Article $43 \mathrm{~g}$ ) EC Treaty). Compared to a requirement of at least the majority of the Member States under the Amsterdam Treaty, the Treaty of Nice substantially lowered the threshold necessary for setting up enhanced cooperation. As for the condition under which a recourse to closer cooperation was possible only as a last resort, the Treaty of Nice specifically provided that it should be the responsibility of the Council to verify that the objectives of such cooperation could not have been attained within a reasonable period by applying the relevant provisions of the Treaties (Article 43a EC Treaty). Newly, it was also emphasized that the goal of enhanced cooperation would have to be to reinforce the process of integration and not merely to further the objectives of the EU as under the Amsterdam Treaty (Article 43 a) EC Treaty). The principle of openness of enhanced cooperation was concretised by stressing that

${ }^{16}$ For more detailed treatment of the amendments brought by the Treaty of Nice, see e.g.: I. Pingel, Commentary on Article 43-45 TEU, in: Commentaire Article par Article des Traités UE et CE, ed. I. Pingel, $2^{\mathrm{e}}$ édition, Helbing Lichtenhahn - Dalloz - Bruylant, Bâle-Paris-Bruxelles 2010.

17 Sometimes, referred to also as emergency brake. 
participation in any enhanced cooperation should be open to all Member States, whether at the moment of establishment of enhanced cooperation or at any later stage (Article 43b EC Treaty).

Thirdly, in terms of procedure, the role of the European Parliament was slightly strengthened. Whereas under the Amsterdam Treaty, it was only to be consulted on the issues of closer cooperation, under the Treaty of Nice, where enhanced cooperation related to an area where co-decision applied, the assent of the European Parliament would have to be sought (Article 11 (2) EC Treaty). Supranational element was, thus, intentionally strengthened to the detriment of intergovernmentalism within the framework of the whole mechanism.

Last but not least, Treaty of Nice made a bold step when it permitted, albeit under the special rules, to launch and implement enhanced cooperation within the framework of the Common Foreign and Security Policy or the $2^{\text {nd }}$ Pillar of the EU (Article 27a to 27e TEU). Although it had been predicted this area might be particularly suitable for enhanced cooperation before, different speed in the context of foreign and security policy was clearly a highly sensitive issue. The extension of enhanced cooperation into this area was, therefore, limited and was only to relate to implementation of joint actions or common positions. At the same time, enhanced cooperation was excluded in matters that would have military or defence implications (Article 27(b) TEU).

It was generally thought that by redesigning the mechanism the Treaty of Nice somewhat eased the hurdles with respect to setting up enhanced cooperation stemming from the Amsterdam Treaty, in particular, by abolishing the right of veto of individual Member States. In spite of the redesign, the rules resulting from the Treaties continued to be subject to criticism and it was argued they still expressed the clear preference for the uniformity of European legal framework. ${ }^{18}$ The critical authors were apparently right. No enhanced cooperation under redesigned rules was authorised although the amendments brought about by the Treaty of Nice remained in force for 6 years. On the other hand, the prospect of enhanced cooperation played some role in political scenarios with respect to specific projects again. In this respect, it is mentioned that the prospect of enhanced cooperation was considered several times, namely, it was to have helped to convince Italy to accept the Framework Decision on European Arrest Warrant. ${ }^{19}$

18 F. Amtebrink, D. Kochenov, Towards a More Flexible Approach to Enhanced Cooperation, in: A. Ott, E. Vos, Fifty Years of European Integration: Foundations and Perspectives, T.M.C. Asser Press, The Hague 2009, p. 199.

19 J. Shaw, op. cit. 


\section{Enhanced Cooperation Following the Lisbon Treaty Amendments}

The present rules on enhanced cooperation stem from the Treaty of Lisbon which, in this respect, actually reproduces the non-negligible part of the provisions which were originally contained in the Constitutional Treaty ${ }^{20}$ whose ratification, however, failed. ${ }^{21}$ The Lisbon Treaty which, unlike the Constitutional Treaty, was duly ratified and entered into force in December 2009, has revised and simplified the framework for setting up enhanced cooperation in several respects.

Formally and the most visibly, provisions on enhanced cooperation in the Treaties have been restructured. The general provisions on enhanced cooperation have been divided into two principal parts. In line with the overall formal redesign of the Treaties resulting from the Lisbon Treaty, basic provisions on enhanced cooperation have been included in the TEU (Article 20) while detailed provisions laying down the conditions and procedure for establishing enhanced cooperation have been inserted into TFEU (articles 326 to 334). These general provisions have been complemented by special provisions on new forms of enhanced cooperation within the framework of common foreign and security policy (Article 42 (6) and $46 \mathrm{TEU}$ ) and special provisions which provide for derogations from the general regime where enhanced cooperation shall be set up in area of freedom, security and justice (in particular, Article 82 (3), 83 (3), 86 (1) and 87 (3) TFEU). Typically for the Lisbon arrangements, a special clause passerelle has been newly included which allows for shift from unanimity to qualified majority vote when authorising enhanced cooperation in the Council of the EU and from special legislative procedure to ordinary legislative procedure when adopting acts pertaining to enhanced cooperation in the Council of the EU (Article 333 TFEU).

As under the previous wordings of the Treaties, a set of material conditions must be principally fulfilled so that enhanced cooperation can be authorised and implemented. In line with the amended provisions of the TEU in conjunction with those of TFEU, enhanced cooperation

i) may be only authorised where at least 9 Member States have requested its authorisation (Article 20(2) TEU), i.e. minimally the number equal to c. $1 / 3$ of all the Member States shall have an interest in setting up enhanced cooperation so that it is guaranteed that it is not a minority issue which might lead to split of the EU into an array of minor alliances;

20 Treaty establishing a Constitution for Europe, signed on 13 December 2007.

21 See its Articles I-44 and Articles III-416 to III-423. 
ii) shall aim to further the objectives of the Union, protect its interests and reinforce its integration process (Article 20(1) TEU), i.e. enhanced cooperation can only be authorised as long as there is the lack of agreement between the Member States on a pan-EU level over a measure or a policy that is fully consistent with the overall goals of the EU and as long as enhanced cooperation may contribute to further integration where a compromise cannot be found;

iii) can be only set up within the scope of the EU's non-exclusive competences (Article 20(1) TEU in conjunction with Article TFEU), i.e. can only be launched in area where the EU has been conferred powers (i.e. not in an area which lies outside the scope of the EU powers) and where the exercise of these powers does not rest exclusively with the EU (which means enhanced cooperation is limited to areas where the EU has been conferred shared or complementary powers);

iv) can only be authorised as a last resort, when it has been established that the objectives of such cooperation cannot be attained within a reasonable period by the EU as a whole (Article 20(2) TEU), i.e. enhanced cooperation can only be introduced as ultima ratio where the prospect of the joint action on a pan-EU level has turned out to be impossible due to the inability to reach an agreement between all the Member States in the foreseeable future; unlike under the previous wordings of the Treaties, impossibility to reach an agreement in a reasonable period shall be sufficient and establishment of enhanced cooperation shall not be necessarily preceded by unsuccessful attempt to reach a decision by applying the relevant provisions of the Treaties;

v) shall comply with the Treaties and the rest of EU law (Article 326 TFEU), i.e. acts adopted in the framework of enhanced cooperation shall not contradict or even infringe the existing EU law rules applying to all the Member States;

vi) shall not undermine the internal market or economic, social and territorial cohesion and it shall not constitute a barrier to or discrimination in trade between Member States, nor shall it distort competition between them (Article 326 TFEU), i.e. enhanced cooperation must always respect the principles of the internal market and undistorted competition in this market which, thus, appear as the core and non-derogable elements of the whole integration process;

vii) shall respect the competences, rights and obligations of those Member States which do not participate in it (Article 327 TFEU), i.e. enhanced cooperation shall not be authorised where its direct or 
indirect goal shall be orientated against one or more Member States which were not willing to participate in integration project or where the effects of enhanced cooperation shall curb the rights of one or more Member States which do not participate in the project;

viii) shall be open to all Member States which shall be free to join enhanced cooperation (Article 20(1) TEU in conjunction with Article 328 (1) TFEU), whether at the moment of its authorisation (subject to compliance with any conditions of participation laid down by the authorising decision) or at any later stage (subject to compliance with the acts already adopted within the given enhanced cooperation, in addition to conditions of participation laid down by the authorising decision), i.e. enhanced cooperation must be necessarily built on the principles of openness and transparency which shall restrict exclusionary character of any enhanced cooperation. ${ }^{22}$

As for procedural aspects, authorisation of enhanced cooperation as such rests with the Council of the EU which, in extension to the model set out by Treaty of Nice, continues to vote on authorisation by a qualified majority. ${ }^{23}$ However, pursuant to the Lisbon Treaty, Member States lost the right to refer the matter to the European Council which they were guaranteed by the Treaty of Nice as a recompense for the loss of the right of veto they originally enjoyed under the Amsterdam Treaty.

As under the previous wordings of the Treaties, the Council of the EU may authorise enhanced cooperation with respect to certain project or certain area only on a proposal from the European Commission. ${ }^{24}$ It is worth noting that, under Article 326 (1) TFEU, the European Commission (voting by the simple majority of the Commissioners from all the Member States) is not legally bound by the initiative of the Member States to launch enhanced cooperation. It may, thus, agree to submit a proposal for authorisation of enhanced cooperation to the Council of the EU but it may also decline to do so. In the latter case, the European Commission is merely obliged to inform the Member States concerned of the reasons for not submitting the proposal to the Council of the EU.

22 For more detailed treatment, see e.g.: G. Isaac, M. Blanquet, op. cit., pp. 48-49 or D. Thym, op. cit., pp. 43-49.

23 Except for enhanced cooperation in the area of the common foreign and security policy which is subject to vote by unanimity, see: Article 329 (2) TFEU.

${ }^{24}$ In case of enhanced cooperation in common foreign and security policy, however, the European Commission still gives only its opinion, in particular, on whether the enhanced cooperation proposed is consistent with other EU policies; High Representative of the EU for Foreign Affairs and Security Policy gives an opinion on whether the proposed enhanced cooperation is consistent with the EU's common foreign and security policy as such, see: Article 329 (2) TFEU. 
What is a real novelty, the Council of the EU is now permitted to authorise enhanced cooperation only upon the prior consent of the European Parliament (Article 329(1) TFEU). While, under Treaty of Nice, consent of the European Parliament was needed only where enhanced cooperation pertained to area covered by co-decision, with the Lisbon Treaty, parliamentary consent has been transformed into a universal requirement which, in turn, increases the number of institutional actors involved in the authorisation procedure. ${ }^{25}$

Thus, although the initiative to launch enhanced cooperation lies with Member States, the requirements of the formal proposal from the European Commission and the consent of the European Parliament actually pose a filter on the freedom of Member States to set up enhanced cooperation. These requirements can be clearly seen as a part of the procedural "checks and balances" against "subversive" or "abusive" initiatives to set up enhanced cooperation that would attempt at circumventing the material conditions prescribed for establishment of enhanced cooperation by the Treaties or that would aim at achieving the goals incompatible with the fundamental political principles of the European integration. As a whole, the Lisbon Treaty has further strengthened supranational control over the intergovernmental initiatives in the sphere of enhanced cooperation. ${ }^{26}$

In the sake of completeness, it shall be added that there is yet another supranational institution which may be involved in the process of control of the authorisation process and that is the Court of Justice of the EU (ECJ). In line with its general mission to ensure that the law is observed in the interpretation and application of the Treaties (Article $19 \mathrm{TEU}$ ), the ECJ is not only competent but, as the postLisbon practice has shown, also willing to rule on interpretation of the provisions of the TEU/TFEU pertaining to enhanced cooperation and, in addition, to scrutinize legality of acts adopted in the course of setting up enhanced cooperation. As there are no self-evident legal standards which would permit for an easy scrutiny of issues such as last resort rule, it is not, however, surprising that, up to now, the ECJ has exhibited

25 Except for enhanced cooperation in common foreign and security policy where the European Parliament is only informed of the request for authorisation, see: Article 329 (2) TFEU.

26 Although political scientists are no doubt right in saying that this control is by definition more efficient with respect to medium-sized and small Member States than to big Member States which, due to their bigger representation in the European Commission and European Parliament and their overall impact, are better positioned to assert their will in supranational institutions. 
a certain degree of judicial self-restraint with respect to judicial control of enhanced cooperation ${ }^{27}$.

It is only upon the adoption of the authorisation decision by the Council of the EU that Member States participating in the enhanced cooperation concerned may adopt legal acts which implement enhanced cooperation. The adoption takes place within the framework of the Council of the EU but while non-participating Member States are allowed to take part in deliberations, only representatives of the participating Member States may take a vote (Article 330 TFEU). Pursuant to Article 20 (4) TEU which reproduces the principle established already by the Amsterdam Treaty, the ensuing acts are binding only on Member States participating in the enhanced cooperation concerned. The same applies to the costs of enhanced cooperation which shall be principally borne by the participating Member States, unless (improbably) stipulated otherwise by all the Members of the Council of the European Union after consulting the European Parliament (Article 332 TFEU). Moreover, the acts adopted within any enhanced cooperation do not form a part of the acquis which has to be accepted by third States which are candidates for the accession to the EU (Article 20 (4) TEU).

\section{Practice of Enhanced Cooperation in the Post-Lisbon Period}

In spite of the amendments brought about by the Lisbon Treaty, many commentators including those who were close to the process of elaboration of the Lisbon Treaty still seemed to be sceptical as to the prospect of the recourse to enhanced cooperation. ${ }^{28}$ However, in the post-Lisbon EU, enhanced cooperation has become reality.

Since the entry of the Lisbon Treaty into force, enhanced cooperation has been authorised in 5 cases in total. So far, in 4 of these 5 cases, implementing acts have been adopted, i.e. in 4 cases enhanced cooperation has materialized in practice. Of these 5 cases, 1 pertains to enhanced cooperation in area of freedom, security and justice, the remaining 4 to general policies of the EU. In a chronological order, enhanced cooperation has been set up with a goal of

27 ECJ, C-274/11 and C-295/11 Kingdom of Spain and Italian Republic v Council of the European Union [2013] ECLI:EU:C:2013:240; C-209/13 United Kingdom of Great Britain and Northern Ireland v Council of the European Union [2014] ECLI:EU:C:2014:283; see also: C-147/13 Kingdom of Spain v Council of the European Union [2015] ECLI:EU:C:2015:299.

28 J.C. Piris, The Lisbon Treaty. A Legal and Political Analysis, Cambridge University Press, Cambridge 2010, pp. 89-90. 
i) unifying the law applicable to divorce and legal separation ("Rome III Regulation"); enhanced cooperation was both authorised ${ }^{29}$ and implemented ${ }^{30}$ in 2010; so far, 17 Member States have participated ${ }^{31}$;

ii) creating of the unitary patent protection system in the EU; enhanced cooperation was authorised upon a request of 26 Member States in $2011^{32}$ and implemented in the course of $2012^{33}$; it is notable that 1 Member State which was originally a fierce opponent of the system, has joined enhanced cooperation since then (Italy) ${ }^{34}$;

iii) establishing financial transaction tax; enhanced cooperation was authorised upon a request of 11 Member States of the Eurozone ${ }^{35}$ at the end of the financial crisis in $2013^{36}$; due to sensitive issues involved, directive implementing enhanced cooperation in the area of financial transaction tax has not, however, been adopted yet ${ }^{37}$; moreover, in 2014 one Member States (Estonia) withdrew from negotiations;

iv) defining the jurisdiction, applicable law and the recognition and enforcement of decisions on the property regimes of international couples; enhanced cooperation was authorised in $2016^{38}$ and

${ }^{29}$ Council Decision 2010/405/EU of 12 July 2010 authorising enhanced cooperation in the area of the law applicable to divorce and legal separation, OJ L 189, 22 July 2010, p. 12.

30 Council Regulation (EU) No 1259/2010 of 20 December 2010 implementing enhanced cooperation in the area of the law applicable to divorce and legal separation, OJ L 343, 29 December 2010.

31 Belgium, Bulgaria, Estonia, Germany, Greece, Spain, France, Italy, Latvia, Lithuania, Luxembourg, Hungary, Malta, Austria, Portugal, Romania and Slovenia.

32 Council Decision 2011/167/EU of 10 March 2011 authorising enhanced cooperation in the area of the creation of unitary patent protection, OJ L 76, $22 \mathrm{March}$ 2011, p. 53.

33 Regulation (EU) No 1257/2012 of the European Parliament and of the Council of 17 December 2012 implementing enhanced cooperation in the area of the creation of unitary patent protection, OJ L 361, 31 December 2012, p. 1.

34 Belgium, Bulgaria, the Czech Republic, Denmark, Germany, Estonia, Ireland, Italy, Greece, France, Cyprus, Latvia, Lithuania, Luxembourg, Hungary, Malta, the Netherlands, Austria, Poland, Portugal, Romania, Slovenia, Slovakia, Finland, Sweden and the United Kingdom.

35 Austria, Belgium, Germany, Estonia, France, Greece, Italy, Portugal, Slovakia, Slovenia and Spain.

36 Council Decision 2013/52/EU of 22 January 2013 authorising enhanced cooperation in the area of financial transaction tax, OJ L 22, 25 January 2013, p. 11.

37 Proposal for a Council Directive implementing enhanced cooperation in the area of financial transaction tax, $\operatorname{COM}(2013) 71$ final of 14 February 2013.

38 Council Decision (EU) 2016/954 of 9 June 2016 authorising enhanced cooperation in the area of jurisdiction, applicable law and the recognition and enforce- 
implemented in the same year ${ }^{39}$; so far, 18 Member States have participated in $\mathrm{it}^{40}$;

v) establishing the European Public Prosecutor's Office; this very first enhanced cooperation area of freedom, security and justice was authorised under special Treaty rules (Article 86 (1) TFEU) ${ }^{41}$ and was implemented in 201742; so far, 20 Member States have participated in this enhanced cooperation. ${ }^{43}$

In this light, while it may be a bit exaggerated to state "the Member States develop a sort of routine to realise policy objectives that cannot be agreed upon by all Member States by means of enhanced cooperation" ${ }^{44}$ not only enhanced cooperation has ceased to be a mere theoric mechanism but its use has undoubtedly gained in dynamics in the post-Lisbon period as well. On a whole, it is quite clear that enhanced cooperation which has been set up so far, has not brought about multi / two-speed Europe of the kind political and legal scientists have traditionally feared of. In this respect, the operation of enhanced cooperation can be described as smooth indeed..$^{45}$

It is somewhat more difficult to assess the precise effects enhanced cooperation has had on political level. In some cases (such as Rome

ment of decisions on the property regimes of international couples, covering both matters of matrimonial property regimes and the property consequences of registered partnerships, OJ L 159, 16 June 2016, p. 16.

39 Council Regulation (EU) 2016/1103 of 24 June 2016 implementing enhanced cooperation in the area of jurisdiction, applicable law and the recognition and enforcement of decisions in matters of matrimonial property regimes, OJ L 183, 8 July 2016, p. 1; Council Regulation (EU) 2016/1104 of 24 June 2016 implementing enhanced cooperation in the area of jurisdiction, applicable law and the recognition and enforcement of decisions in matters of the property consequences of registered partnerships, OJ L 183, 8 July 2016, p. 30.

40 Austria, Belgium, Bulgaria, Croatia, Cyprus, Czech Republic, Finland, France, Germany, Greece, Italy, Luxembourg, Malta, Netherlands, Portugal, Slovenia, Spain and Sweden.

41 Under this provision, authorisation of enhanced cooperation on this issue is deemed to be granted where, in case of disagreement on a pan-European level, at least nine Member States notify the European Parliament, the Council of the EU and the European Commission that they wish to establish enhanced cooperation on the basis of the draft regulation on establishment of the European Public Prosecutor's Office.

42 Council Regulation (EU) 2017/1939 of 12 October 2017 implementing enhanced cooperation on the establishment of the European Public Prosecutor's Office, OJ L 283, 31 October 2017, p. 1.

43 Austria, Belgium, Bulgaria, Croatia, Cyprus, Czech Republic, Germany, Estonia, Finland, France, Greece, Italy, Latvia, Lithuania, Luxembourg, Portugal, Romania, Slovakia, Slovenia and Spain.

44 R. Böttner, op. cit., p. 82.

45 D. Thym, op. cit., p. 41. 
III Regulation or the European Public Prosecutor's Office), enhanced cooperation seemingly resolved the tension between the Member States willing to further integrate and those satisfied with the existing level of integration. In other cases (such as the unitary patent protection system), however, launching enhanced cooperation or a mere prospect of launching enhanced cooperation triggered a political pressure upon Member States which were not originally in favour of further integration and led some of them to change their positions. And, in case of financial transaction tax, launching enhanced cooperation even between a restrained group of Member States, has not resulted into implementing it and has even caused one Member State to withdraw from the process. This shows there might be situations where it may be illusionary to perceive enhanced cooperation as an easy way how to cope with the differing views of the Member States and permit the coalitions of the willing to quickly proceed with further integration.

In these circumstances, although enhanced cooperation may apparently provide a useful alternative to uniform decision-making in the EU, one would be tempted to say it is not a magic panacea for any of sort of differences and conflicts within the EU as it might seem at the first sight. The future practice will definitely shed more light on the full potential of enhanced cooperation.

\section{Czech Republic and Enhanced Cooperation}

Taking into account the fact enhanced cooperation has been employed several times in the recent decade in order to deepen integration in limited but important areas and, also, that it could play role were the EU to develop in line with Scenario 3 identified by the European Commission in 2017, positions of individual Member States with respect to theory and practice of enhanced cooperation matter.

In case of the Czech Republic which, in the past, strongly pleaded for the delimitation of the powers of the EU and the respect for the powers of Member States during the negotiations leading to conclusion of the Lisbon Treaty and which is now frequently considered to belong to Eurosceptic Member States, it might be expected the enhanced cooperation and other instruments that permit for differentiation in the EU shall be subject to intense political debate and shall occupy a non-negligible place within the EU politics pursued by the Czech Republic.

However, at least for the time being, it does not seem to be the case.

Despite such state, the truth is that the instrument of enhanced cooperation did not come unnoticed in the Czech Republic. As early as in 2009, at the occasion of ratification of the Lisbon Treaty in the Czech Republic, the procedural conditions of launching enhanced cooperation 
in the EU even became subject to legal proceedings. When, for the second time, a group of senators seized the Czech Constitutional Court over the compatibility of the Lisbon Treaty with the Czech Constitution before the Lisbon Treaty was ratified, Senators challenged inter alia the amendments the Lisbon Treaty sought to introduce into the mechanism of enhanced cooperation as laid down by the Treaty of Nice. ${ }^{46}$ In particular, the Senators argued that Article 20 TEU as amended by the Lisbon Treaty would conflict with the Article 1(1) and Article 10 of the Czech Constitution as long as "by making the enhanced cooperation conditional upon the consent of the EU institutions, it shall bar the exercise of certain powers both on European and national level and, as such, it is inconsistent with the principle of popular sovereignty and that of sovereignty of the Czech Republic". ${ }^{47}$ In other words, Senators indirectly criticized that, under the Lisbon amendments, enhanced cooperation could only be achieved upon a proposal from the European Commission and the consent of the European Parliament. In its Lisbon II judgment, the Czech Constitutional Court, however, dismissed the challenge arguing i.a. that enhanced cooperation as amended by the Lisbon Treaty did not conflict with either popular sovereignty or sovereignty of State as, pro futuro, it would be left upon the will of the Czech Republic's constitutional bodies including the both houses of the Parliament whether, when and in which form the Czech Republic would adhere to the project of the enhanced cooperation or whether it would take advantage of its right to bar such form of different speed of integration processes inside the EU.$^{48}$ Although it is not clear what the Constitutional Court had in mind as we know one of the goals of the Lisbon Treaty was precisely to remove the last traces of the right of veto of individual Member States with respect to setting up enhanced cooperation (which, no doubt, constituted interference with the sovereignty of the Member States), the challenge was a clear sign that at least a part of the political actors did not $a$ priori underestimate the potential the use enhanced cooperation might have on the EU.

At present, however, there seems to be no comprehensive position on enhanced cooperation in the Czech Republic.

As far as the Czech Executive is concerned, in the "Manifesto on the Politics of the Czech Republic in the European Union", ${ }^{49}$ the key conceptual document of the Czech priorities in the EU adopted by

46 Czech Constitutional Court, P1.ÚS 29/09 of 3. November 2009, Lisbon II.

47 Ibidem, para 165.

48 Ibidem, para 166.

49 Adopted on 27 April 2015; https://www.vlada.cz/assets/media-centrum/aktualne/Koncepce-CR-v-EU.pdf (10.11.2018). 
the Cabinet of Bohuslav Sobotka in 2015, the practice of enhanced cooperation is mentioned as reality (in its introduction) but, then, no explicit guidelines are provided with respect to formulating the Czech position on enhanced cooperation and its use in future. At the same time, on one hand, the Manifesto puts a strong emphasize on the Czech Republic taking the full use of the membership in the EU which can be read as a suggestion the Czech Republic shall join the Eurozone and, possibly, also participate in the projects of enhanced cooperation. On the other hand, the Manifesto states the united EU is a key strategic interest of the Czech Republic which makes an impression the Czech Executive is determined to seek the unity in the EU as far as possible. In turn, such strategic interest shall logically reduce the Czech interest in the projects of launching the enhanced cooperation.

As for the Czech Parliament, an opportunity to pronounce on enhanced cooperation "rcently" came with the European Commission's "White paper on the future of Europe". While the Chamber of Deputies limited itself to taking the White paper into consideration, ${ }^{50}$ the Senate dealt with individual Scenarios more in-depth. In its resolution from July 2017, reassuring that "the strategic decisions on the future orientation shall always built upon the consensus of the Member States reached following the in-depth negotiations in the European Council", the Senate clearly stated that "differentiated integration leading to closer cooperation of only some Member States shall be only the last-resort step where goodfaith attempts to reach a settlement acceptable for all the Member States has failed" and that "such form of cooperation shall remain open to all the Member States and must exclude negative impacts on operation of the common policies of the EU and individual Member States". ${ }^{51}$

Thus, as far as the preceding documents allow for generalization, it seems that the Czech Republic is currently more in favour of deepening the integration synchronically and in a uniform manner than of encouraging flexibility and differentiation within the EU. That is interesting because the Czech Republic is often thought to belong to the opposite camp inside the EU.

When it comes to enhanced cooperation in practice, it shall be also mentioned the Czech Republic has participated in 3 of the 5 existing enhanced cooperation and that since their very beginnings. ${ }^{52}$ The Czech

\footnotetext{
50 Chamber of Deputies, Committee for European Affairs, 7th Legislature, Resolution No 388 of 4 May 2017.

51 Senate, 11th Legislature, Resolution No 232 of 20 July 2017.

52 Which means the Czech Republic is more involved in enhanced cooperation than Poland although the Poles are seemingly more pro-European (70\%) than the
} 
Republic has, thus, participated in enhanced cooperation i) on the creation of the unitary patent protection, ii) on jurisdiction, cooperation on applicable law and the recognition and enforcement of decisions on the property regimes of international couples and, most recently, iii) on the creation of the European Public Prosecutor's Office (which is interesting as, in the past, the Czech Republic did not support the idea on the pan-EU level). As for the remaining 2 enhanced cooperation, with respect to that on the law applicable to divorce and legal separation, officially, the Czech Republic has reserved the right to reconsider its position in the light of experience gained by application of the cooperation in practice..$^{53}$ As for the enhanced co-operation on financial transaction tax, it is probably the only enhanced cooperation the Czech Republic was "hostile" to as it abstained during a vote on its authorisation in the Council of the EU. ${ }^{54}$ On the other hand, more recently, the Czech Republic has participated in a novel form of enhanced cooperation introduced by the Lisbon Treaty in area of common foreign and security policy known as permanent structured cooperation in the sphere of defence or, laconically, "Schengen of Defence". 55

\section{Conclusion}

While a decade ago, enhanced cooperation was only a theoretical concept without the real existence, by now, this concept has materialized in 5 cases whose importance cannot be overestimated but which is not minor either. Up to now, enhanced cooperation has not brought about the fragmented and multi / two-speed Europe many commentators feared in the past and it may provide a useful alternative to uniform decision-making in the EU. On the other hand, it does not seem to be a magic panacea for any of sort of differences and conflicts within the EU as it might seem at the first sight. Even though, especially for medium-sized and small Member States

Czechs (60\%), see: the results of the Eurobarometer survey, Democracy on the move - European Elections: One year to go, available at http://www.europarl.europa.eu/ at-your-service/en/be-heard/eurobarometer/eurobarometer-2018-democracy-on-themove (10.11.2018).

53 See: a press report of the Permanent Mission of the Czech Republic to the EU of 10 June 2010 available at https://www.mzv.cz/representation_brussels/cz/ udalosti_a_media/pravidla_pro_rozvody_mezinarodnich.html.

54 See: a press report No $5555 / 13$ of 22 January 2013 available at http://register. consilium.europa.eu/doc/srv? $1=\mathrm{EN} \& \mathrm{f}=\mathrm{ST} \% 205555 \% 202013 \% 20 \mathrm{INIT}$ (10.11.2018).

55 Council Decision (CFSP) 2017/2315 of 11 December 2017 establishing permanent structured cooperation (PESCO) and determining the list of participating Member States, OJ L 331, 14 December 2017, p. 57. 
including the Czech Republic, it may represent a useful instrument these Member States could integrate into their strategy inside the current EU.

\section{References}

Agreement between the Governments of the States of the Benelux Economic Union, the Federal Republic of Germany and the French Republic on the graduat abolition of checks at their common borders, signed on 14 June 1985 and Convention, implementing the Schengen Agreement of 14 June 1985 between the Governments of the States of the Benelux Economic Union, the Federal Republic of Germany and the French Republic on the gradual abolition of checks at their common borders, signed on 19.06.1990.

Amtebrink F., Kochenov D., Towards a More Flexible Approach to Enhanced Cooperation, in: A. Ott, E. Vos, Fifty Years of European Integration: Foundations and Perspectives, T.M.C. Asser Press, The Hague 2009.

Böttner R., The Development of Flexible Integration in EC/EU Practice, in: Flexibility in the EU and Beyond. How Much Differentiation Can European Integration Bear?, eds. T. Giegerich, D.C. Schmitt, S. Zeitzmann, Nomos - Hart Publishing, Baden-Baden-Oxford 2017.

Commentaire Article par Article des Traités UE et CE, ed. I. Pingel, $2^{\mathrm{e}}$ édition, Helbing Lichtenhahn - Dalloz - Bruylant, Bâle-Paris-Bruxelles 2010.

Council Decision (CFSP) 2017/2315 of 11 December 2017 establishing permanent structured cooperation (PESCO) and determining the list of participating Member States, OJ L 331, 14.12.2017.

Council Decision (EU) 2016/954 of 9 June 2016 authorising enhanced cooperation in the area of jurisdiction, applicable law and the recognition and enforcement of decisions on the property regimes of international couples, covering both matters of matrimonial property regimes and the property consequences of registered partnerships, OJ L 159, 16.06.2016.

Council Decision 2010/405/EU of 12 July 2010 authorising enhanced cooperation in the area of the law applicable to divorce and legal separation, OJ L 189, 22.06.2010.

Council Decision 2011/167/EU of 10 March 2011 authorising enhanced cooperation in the area of the creation of unitary patent protection, OJ L 76, 22.03.2011.

Council Decision 2013/52/EU of 22 January 2013 authorising enhanced cooperation in the area of $\mathrm{fi}$ nancial transaction tax, OJ L 22, 25.01.2013. 
Council Regulation (EU) 2016/1103 of 24 June 2016 implementing enhanced cooperation in the area of jurisdiction, applicable law and the recognition and enforcement of decisions in matters of matrimonial property regimes, OJ L 183, 8.07.2016.

Council Regulation (EU) 2016/1104 of 24 June 2016 implementing enhanced cooperation in the area of jurisdiction, applicable law and the recognition and enforcement of decisions in matters of the property consequences of registered partnerships, OJ L 183, 8.07.2016.

Council Regulation (EU) 2017/1939 of 12 October 2017 implementing enhanced cooperation on the establishment of the European Public Prosecutor's Office, OJ L 283, 31.10.2017.

Council Regulation(EU) No 1259/2010 of 20 December 2010 implementing enhanced cooperation in the area of the law applicable to divorce and legal separation, OJ L 343, 29.12.2010.

Czech Constitutional Court, Pl.US 29/09 of 3. November 2009, Lisbon II Chamber of Deputies, Committee for European Affairs, 7 th Legislature, Resolution No 388 of 4.05.2017.

European Commission: "White paper on the future of Europe. Reflections and scenarios for the EU27 by 2025", $\operatorname{COM(2017)~} 2025$ final, 1.03.2017.

Geremek B., L'élargisement et l'unité de l'Europe. Speech pronounced at the annual conference of doctoral studies at Sciences Politiques in Paris, 27 January 2004, https://www.robert-schuman.eu/fr/doc/actualites/ elargissement-geremek.pdf [last accessed on 10 November 2018.

Isaac G., Blanquet M., Droit général de l'Union européenne, $10^{\mathrm{e}}$ édition, Sirey, Paris 2012.

Judgment of the Court (Grand Chamber) of 5 May 2015 Kingdom of Spain v Council of the European Union Action for annulment Implementing enhanced cooperation - Unitary patent - Regulation (EU) No 1260/2012 - Provisions concerning translation - Principle of non-discrimination - Article 291 TFEU - Delegation of powers to bodies outside the European Union - Second paragraph of Article 118 TFEU - Legal basis - Principle of autonomy of EU law, C-147/13.

Judgment of the Court (Grand Chamber), 16 April 2013 Kingdom of Spain and Italian Republic v Council of the European Union Unitary patent - Decision authorising enhanced cooperation under Article 329(1) TFEU - Actions for annulment on grounds of lack of competence, misuse of powers and infringement of the Treaties - Conditions laid down in Article $20 \mathrm{TEU}$ and in Articles $326 \mathrm{TFEU}$ and $327 \mathrm{TFEU}$ - Non-exclusive competence - Decision adopted 'as a last resort' Preserving the interests of the Union, C-274/11 and C-295/11. 
Judgment of the Court (Second Chamber), 30 April 2014 United Kingdom of Great Britain and Northern Ireland v Council of the European Union Common system of financial transaction tax - Authorisation of enhanced cooperation under Article 329(1) TFEU - Decision 2013/52/EU - Action for annulment in respect of infringement of Articles 327 TFEU and 332 TFEU and of customary international law, C-209/13.

Piris J.C., The Lisbon Treaty. A Legal and Political Analysis. Cambridge: Cambridge University Press 2010.

Proposal for a Council Directive implementing enhanced cooperation in the area of financial transaction tax, $\operatorname{COM}(2013) 71$ final, 14.02.2013.

Protocol on certain provisions relating to Denmark and Protocol on certain provisions relating to the United Kingdom of Great Britain and Northern Ireland, OJ C 191, 29 July 1992.

Protocol on Social Policy, to which is annexed an agreement concluded between the Member States of the European Community with the exception of the United Kingdom of Great Britain and Northern Ireland, to which two declarations are attached, OJ C 191, 29.07.1992.

Regulation (EU) No 1257/2012 of the European Parliament and of the Council of 17 December 2012 implementing enhanced cooperation in the area of the creation of unitary patent protection, OJ L 361, 31.12.2012.

Shaw J., Enhancing Cooperation after Nice, in: M. Andenas, J. Usher, The Treaty of Nice and Beyond: Enlargement and Constitutional Reform, Hart Publishing, Oxford 2003.

Stubb A., Negotiating Flexibility in the European Union, Palgrave, Houndmills, 2002, https://doi.org/10.1057/9781403907615.

Thym D., Competing Models for understanding differentiated integration, in: Between Flexibility and Disintegration. The Trajectory of Differentiation in EU Law, eds. B. de Witte, A. Ott, E. Vos, Elgar, Cheltenham- Northampton 2017, https://doi.org/10.4337/9781783475896.00009.

Treaty establishing a Constitution for Europe, OJ C 310, 16.12.2004. Treaty on the Functioning of the European Union, OJ C 326, 26.10.2012. 